Images in...

\title{
Round cell epithelioid GIST (gastrointestinal stromal tumour) in an endoscopic biopsy is a diagnostic confounder
}

\author{
Andleeb Abrari, Urmi Mukherjee, Rajesh Tandon, M Chandrashekhar
}

Histopathology Department, Max Super Specialty Hospital, New Delhi, India

Correspondence to Dr Andleeb Abrari, abrariand@gmail.com

\section{DESCRIPTION}

The authors present a case of a 53-year-old lady, with vague upper gastrointestinal symptoms and progressive iron deficiency anaemia, stool positive for occult blood and progressive weight loss. Endoscopically a lumenally protruding mass, with extensive mucosal ulceration was seen. Carcinoma, stromal tumour and lymphoma were the clinical differential diagnoses. Histologic sections showed a dense, diffuse and adhesive mucosal infiltrate of round cells. The tumour cells were round, with high nuclearcytoplasmic ratios, without any specific cyto-architectural attribute except rare subtle plasmacytoid aspect (figures 1 and 2A,B). A non-Hodgkin lymphoma and poorly differentiated adenocarcinoma were initially considered, and immunochemistry requisitioned. The initial sets of immunomarkers showed the infiltrating cells to be negative for epithelial markers - pan-cytokeratin (CK), antiepithelial membrane antigen and CK 7, or leucocyte, B lymphocyte and plasma cell lineage markers (antileucocyte common antigen, CD 20,CD 79a, CD 138 and CD38). The second phalanx of immunostains included antihuman melanoma antigen (HMB) 45, Vimentin, S-100, Desmin, Ki-67, CD 117 and $\mathrm{CD} 34$. The tumour cells were observed to diffusely label with CD117, vimentin and CD34, and unmarked by HMB 45, S-100 (melanoma markers) and desmin (muscle). With this immunoprofile, a histologic diagnosis of gastrointestinal stromal tumour (GIST) was rendered and was confirmed upon examination of the surgical resection specimen (figure 2C). Gastrointestinal stromal tumours are the most common mesenchymal tumours affecting all segments of the gastrointestinal tract, arising from the interstitial cells of Cajal, in the muscularis propria. These tumours equally affect female and male patients, with more than $75 \%$ of the cases occurring in patients older than 50 years. Five per cent of the lesions arise in the oesophagus, $50 \%$ in the stomach, $25 \%$ in the small bowel and $10 \%$ in the colon and rectum. ${ }^{1-3}$ GISTs in $70 \%$ of cases are composed of spindle cells, in $20 \%$ of epithelioid cells, and the remainder have a mixed cellular composition. ${ }^{3}$ GISTs with epitheloid features often have large polygonal cells with abundant

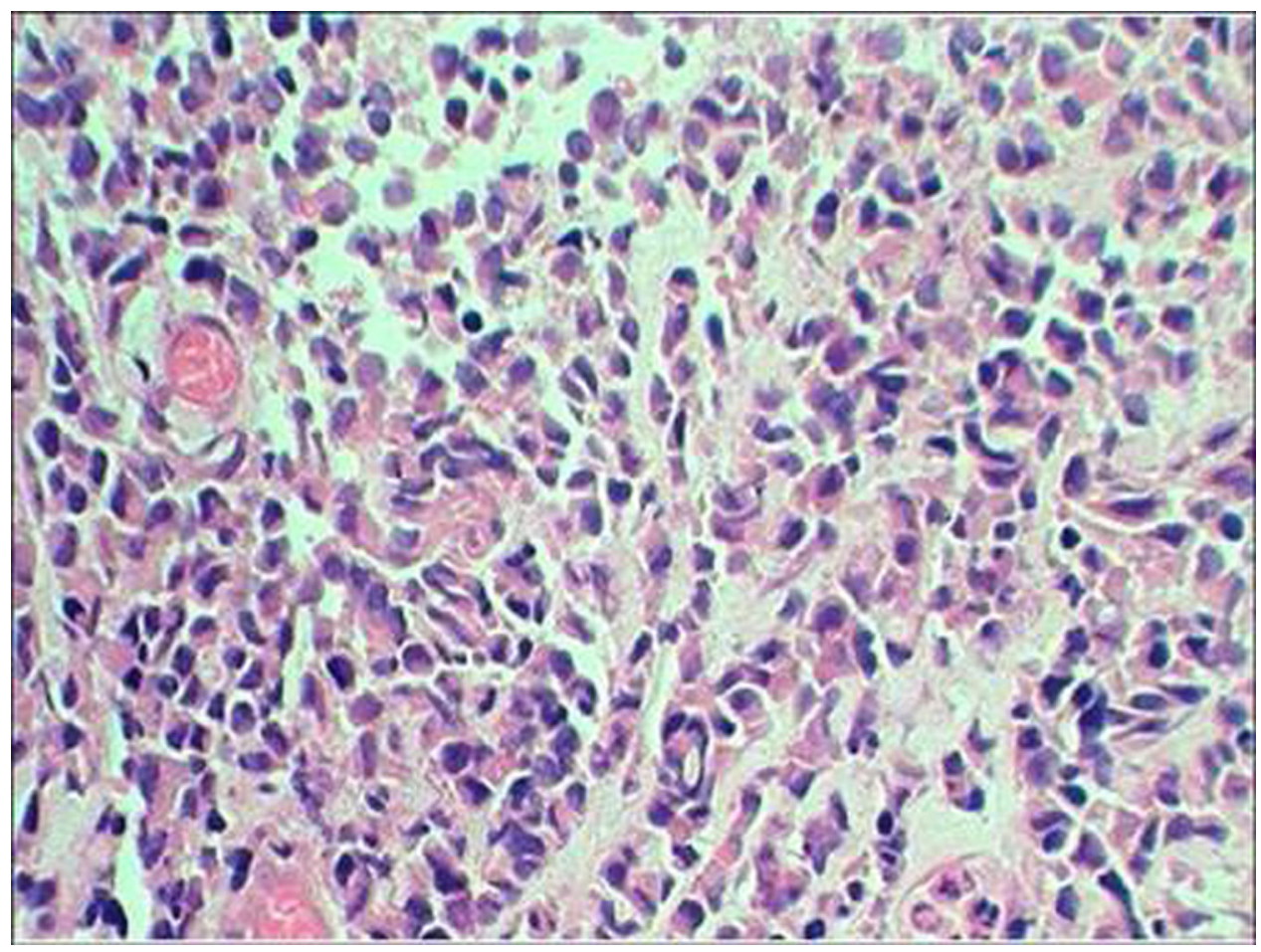

Figure 1 Mucosal infiltrate by largely homomorphous round cells. 


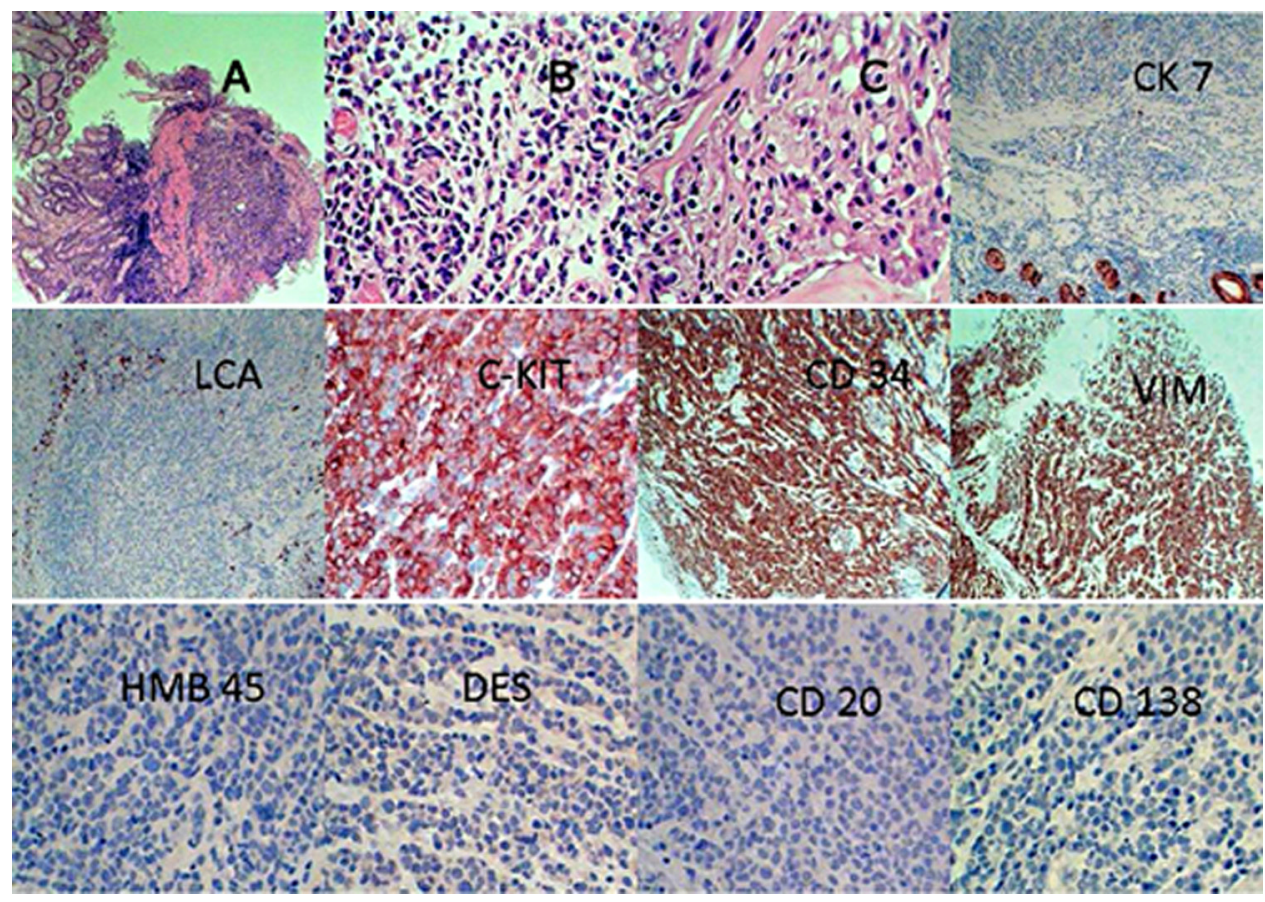

Figure 2 Image panels of gastric mucosal biopsy showing infiltration of mucosa by dehesive round cells. (A, B) Histology in the surgically resected specimen showing is similar. (C) Immunoperoxidase stains demonstrate expression of CD117, CD34 and vimentin.

cytoplasm and indistinct cell borders. They may be multinucleated and may thus display focal pleomorphism not usually found in spindle cell tumours. ${ }^{2}$ Since not all mesenchymal lesions of the gastrointestinal tube are GISTs, and a tissue diagnosis is imperative, preoperatively - obtaining a tissue specimen through invasive means is extremely desirable. Imaging (CT, endoscopic ultrasound) impressions are at best presumptive, with issues of ready accessibility and costs involved; and modalities like endoscopic ultrasound guided fine needle aspiration - will yield cytology smears - not yet optimal samples for the GIST defining immunostains - endoscopic biopsy is, and will be the first essay in the investigation of presumptive GISTs, even with the accepted limitations of yield in sub mucosal/ mural lesions. Tumours with monomorphous cellularity as the one described in the present case will have a broad histologic differential including undifferentiated/poorly differentiated carcinoma, lymphoma, plasmactoma, rhabdomyosarcoma, neuroendocrine tumour, rhabdoid tumour and synovial sarcoma. Suspicion index, clinico-pathologic correlation and a broad spanning immunohistochemistry panel will resolve the diagnosis in the majority of cases.

\section{Competing interests None.}

Patient consent Obtained.

\section{REFERENCES}

1. Pidhorecky I, Cheney RT, Kraybill WG, et al. Gastrointestinal stromal tumors: current diagnosis, biologic behavior, and management. Ann Surg Oncol 2000; 7:705-12.

2. Miettinen $\mathbf{M}$, Lasota J, Sobin LH. Gastrointestinal stromal tumors of the stomach in children and young adults: a clinicopathologic, immunohistochemical, and molecular genetic study of 44 cases with long-term follow-up and review of the literature. Am J Surg Pathol 2005;29:1373-81.

3. Fletcher CD, Berman JJ, Corless C, et al. Diagnosis of gastrointestinal stromal tumors: A consensus approach. Hum Pathol 2002;33:459-65.

This pdf has been created automatically from the final edited text and images.

Copyright 2011 BMJ Publishing Group. All rights reserved. For permission to reuse any of this content visit http://group.bmj.com/group/rights-licensing/permissions.

BMJ Case Report Fellows may re-use this article for personal use and teaching without any further permission.

Please cite this article as follows (you will need to access the article online to obtain the date of publication).

Abrari A, Mukherjee U, Tandon R, Chandrashekhar M. Round cell epithelioid GIST (gastrointestinal stromal tumour) in an endoscopic biopsy is a diagnostic confounder. BMJ Case Reports 2011;10.1136/bcr.10.2011.4996, Published XXX

Become a Fellow of BMJ Case Reports today and you can:

- Submit as many cases as you like

- Enjoy fast sympathetic peer review and rapid publication of accepted articles

- Access all the published articles

- Re-use any of the published material for personal use and teaching without further permission

For information on Institutional Fellowships contact consortiasales@bmjgroup.com

Visit casereports.bmj.com for more articles like this and to become a Fellow 